\title{
Farklı Siyasalarda Devletin Kurumsal Girişimciliğini Yeniden Düşünmek: Türkiye Bağlamında Bir Tipoloji Önerisi")
}

Rethinking the State's Institutional Entrepreneurship in Different Policies: A Typology for the Turkish Context

\author{
Fatih Mehmet Bulut ${ }^{(*)}$ \\ Yücel Sayılar ${ }^{(* *+)}$
}

\begin{abstract}
Özet
Yeni kurumsal kuramın liberal sistemde tarafsız, tutarlı, tek tip ve kurumsal alanların dışında bir kurumsal aktör olarak resmettiği devlet kavramının ve devletin kurumsal girişimci rolünün farklı ulusal bağlamlarda ve farklı devlet sistemlerinin hâkim olduğu ülkelerdeki geçerliliği tartışmaya açıktır. Türkiye koşullarından yola çıkarak yapılan çalışmalar incelendiğinde, devletin sahip olduğu kendine özgü siyasa ile birlikte, farklı kurumsal alanlarda farklı motivasyonlarla hareket ettiği gözlemlenmektedir. Bu çalışmada, liberal sistemde kavramlaştırılan devletin kurumsal girişimciliğinden farklı olarak Türkiye'de devletin toplumu kontrol etme ve kaynakların (siyaseten) yeniden dağılımını önceleme biçimde tanımlanan iki boyutla açıklanabilecek şekilde hareket ettiği öne sürülmektedir. Ortaya konan tartışma, devletin kurumsal girişimci rolüne ve gerçekleştirdiği kurumsal işlere yönelik açıklayııı bir çerçeve geliştirmeyi amaçlamaktadır.
\end{abstract}

Anahtar kelimeler: Yeni kurumsal kuram, Türkiye, kurumsal girişimcilik, devlet, siyasa farklılıkları

(*) Bu çalışma XII. Örgüt Kuramı Sempozyumunda sunulan "Siyasa Farklılığının Devletin Kurumsal Girişimci Rolüne ve Kurumsal Alanlardaki Davranışlarına Etkisi" başılıkı bildirinin genişletilmiş halidir.

(**) Sorumlu yazar/Corresponding author, Nişantaşı Üniversitesi, İktisadi, İdari ve Sosyal Bilimler Fakültesi, İşletme (İngilizce) Bölümü, Sarıyer/İstanbul,fatih.bulut@nisantasi.edu.tr, ORCID No: 0000-0002-1143-2592

(**) Bursa Uludağ Üniversitesi, İktisadi ve İdari Bilimler Fakültesi, İşletme Bölümü, Görükle/Bursa, ysayilar@uludag.edu.tr, ORCID No: 0000-0001-6226-0324 


\begin{abstract}
The validity of the concept of the state and the institutional entrepreneurial role of the state, which the new institutional theory portrays in the liberal system as a neutral, coherent, uniform, and institutional actor outside of the institutional fields, is open to discussion in different national contexts and countries where different state systems are dominant. When the studies conducted in the context of Turkey are examined, it would be observed that the state acts with different motivations in different institutional fields, along with its own unique politics. In this study, we that, unlike the institutional entrepreneurship of the state conceptualized in the liberal system, the way the state in Turkey acts can be explained by two dimensions defined in terms of controlling society and prioritizing the redistribution of resources (politically). The discussion set out aims to develop an explanatory framework for the role of the state as an institutional entrepreneur and the institutional work it performs.
\end{abstract}

Keywords: New institutional theory, Turkey, institutional entrepreneurship, state, political differences

\title{
Giriş
}

Yeni kurumsal kuram, farklı coğrafyalarda hâkim kurumların özellikleri, bu kurumları, kurumsal alanları oluşturan ve değiştiren aktörlerin doğasına ilişkin varsayımları açısından ağırlıklı olarak Anglo-Amerikan dünyada şekillenmekle birlikte, varsayımlarının farklı kurumsal bağlamlarda yeniden düşünülmesine izin veren bir derinliğe de sahiptir. Bu anlamda bir kurumsal aktör olarak devlet kavramsallaştırması, yeni kurumsalcı kuramın hâkim varsayımlarını rasyonalite, yerleşiklik, kapitalist sistem ve iktisadi eylemin politik doğası gibi olgular üzerinden tartışmaya imkân veren araçlardan biridir. Yeni kurumsal kuramın temel iddiası, örgütlerin verimliliklerini artırmak amacıyla sadece teknik çevrenin şartlarına uyum sağlayarak değil, bulundukları kurumsal çevrede meşruiyet temin etmek amacıyla da kurumsal çevrenin dayattığı kurumları -verimliliklerini azaltmış olsa bile- benimseyerek yaşamlarını sürdürdükleri yönündedir. Yeni kurumsal kuramda, kurumların, çeşitli şekillerde sosyal olarak inşa edilmiş, rutin olarak yeniden üretilmiş programlar veya kural sistemleri olarak tanımlanması, kurumsal değişimin nasıl gerçekleştiğinin tartışmaya açılmasına neden olmuştur. Yani, eylemleri, niyetleri ve rasyonelliğinin tümü, değiştirmek istedikleri kurumlar tarafından her şartta belirleniyorsa, aktörler kurumları nasıl değiştirebilir (Holm, 1995) sorusuna/paradoksuna cevap aranmaktadır. Kurumsal belirlenimcilik ile eyleyen arasındaki bu paradoks "gömülü eyleyen paradoksu" olarak nitelendirilmiştir (Seo \& Creed, 2002). Bu paradoks kurumsal kuram çerçevesinde aktör- yapı tartışmasına karşılık gelmektedir. 
Kurumsal değişimin açıklanmasında aktörü ön planda tutan çalışmalar ile ortaya "kurumsal girişimci" kavramı atılmışır (Garud, Hardy \& Maguire, 2007). Yazında bu kavramı ilk kullananlardan biri olan DiMaggio (1988), kurumsal girişimcileri uygun gördükleri ve çıkarlarıyla uyumlu olduklarını düşündükleri kurumların oluşturulmasını destekleyen "meşruiyet aracıları" olarak tanımlamaktadır. Ayrıca, bu kurumsal aktörlerin, kurumların karakterini ve kurumsal değişimi şekillendirecek kaynaklara ve dolayısıyla güce sahip olduklarını belirtmektedir (DiMaggio, 1988). Buradan hareketle devletin yasal gücünü kullanarak örgütsel/ kurumsal alanlarda kurumsal değişimi gerçekleştirecek kurumsal aktörlerden biri olduğu ifade edilmektedir (Nasra \& Dacin, 2010).

Öte yandan, kurumsal iş kavramı da devletin farklı kurumsal alanlarda yüklendiği rollerin daha net biçimde tanımlanmasına ve açıklanmasına yardımcı olmaktadır. Kurumsal iş kavramını ilk ortaya atan Lawrence ve Suddaby (2006) kavramı kurumsal aktörlerin (bireysel veya örgütsel) kurumları oluşturmak, sürdürmek (destek vermek) veya var olan kurumları yok etmek için bilinçli olarak gerçekleştirdikleri eylemlerin tümü olarak tanımlamışlardır. Kurumsal iş, bireylerin ve kolektif aktörlerin, içinde yaşadıkları, çalıştıkları, onlara rollerini, ilişkilerini, kaynaklarını ve günlük rutinlerini veren yeni kurumsal yapılarla başa çıkma, ayak uydurma, güçlendirme, yıkma, tamir etme, dönüştürme veya oluşturma çabalarını ifade eden bir kavramdır (Lawrence, Suddaby \& Leca, 2011). Bu çalışmada da devletin kurumsal alanlarda gösterdiği eylemler, diğer bir deyişle giriştiği kurumsal işler üzerinden oynadığı rol anlaşılmaya çalışılmaktadır.

Liberal sistemin egemen olduğu siyasalarda (ör: ABD) kurumsal alanları rasyonelleştiren en büyük aktörlerden birisi olarak kavramlaştırılan devletin (DiMaggio \& Powell, 1991), farklı siyasalarda (ör: devletçi siyasada) yapılan çalışmalar dikkate alındığında aynı şekilde kavramlaştırılması pek mümkün gözükmemektedir. Türkiye bağlamında devletin bir kurumsal aktör olarak üstlendiği rollerin Amerikan kurumsalcılığının siyasal sistem varsayımları ile tam olarak örtüşmeyebileceği fikri, ilk olarak Özen (2010) tarafından ortaya konmuştur. Özen (2010), Türkiye'deki hâkim devlet pratiğini göz önünde bulundurarak, devletin kurumsal alanları rasyonelleştiren bir aktör olmadığı ve aksine kurumsal alanlarda belirsizliğe yol aç九tğı; alanların dışında bir aktör olarak değil, alanlara dahil bir oyuncu olarak eylemde bulunduğu savını öne sürmüştür.

$\mathrm{Bu}$ çalışmanın konusunu farklı siyasalarda değişen devlet kavramlaştırması doğrultusunda devletin farklı kurumsal alanlarda gösterdiği eylem değişikleri ve 
bu değişikliklerin olası dayanakları oluşturmaktadır. Bir kurumsal girişimci olarak devletin, anglo-sakson dünya ve liberal iktisadi-devlet sistemi varsayımlarının dışında kalan bir kurgu içinde hangi kurumsal işlere girişebileceği ve devleti bu yönde harekete geçiren, dolayısıyla da yeni kurumsalcı gelenekteki devlet tahayyülünden farklılaştıran saiklerin neler olabileceği tartışmaya açılmaktadır. Türkiye'de bir kurumsal girişimci olarak devletin rolü ve kurumsal işlerine ilişkin yazın, önemli bir çıkış noktasını oluşturmaktadır (Özen, 2014; Yalçınkaya \& Taşcı, 2017; Yalçınkaya, 2018; Yalçınkaya \& Taşcı, 2020). Bu çalışma, iki açıdan önceki araştırmalardan farklılaşmakta ve ilgili sorunsalı bir adım öteye taşıyabilmeyi amaçlamaktadır: (1) Devletin kurumsal girişimci rolündeki farklılaşmanın ana sebeplerini tartı̧̧mak ve kurumsal işlerinin değişimine açıklayıcı boyutlar kazandırmak, (2) devletin kurumsal girişimci olarak oynadiğ rolü farklllaștıran temel sebepleri göz önüne alarak, farklı kurumsal iş tipolojileri tanımlamak ve bu tipolojiler üzerinden devletin eylemlilïginin araştrrlmasına analitik bir zemin hazırlamak. Bu şekilde, çalısma, Türkiye bağlamından hareketle, farklı siyasaya sahip bir ülkede, devletin kurumsal alanlarla ilişkisinde sergilediği eylemsel değişkenliğin nedenlerini ortaya koymaya ve devletin olası kurumsal işlerini tanımlayarak açılamaya yönelmektedir.

Çalışmanın bundan sonraki bölümlerinde öncelikle yeni kurumsalcı perspektiften kurumsal girişimci kavramı ile liberal sisteme özgü devlet anlayışı üzerinde durulmaktadır. Daha sonra siyasa farklılıklarının devlet kavramsallaştırmalarına etkilerine değinilmektedir. Ayrıca, buna bağlı olarak devletin kurumsal alanlardaki değişen rolleri incelenmektedir. Devamında, Türkiye bağlamında devletin kurumsal aktör olarak kurumsal alanlarda gösterdiği eylem değişiklikleri üzerinde durulmaktadır. Diğer bir ifade ile devletin değişen kurumsal alanlarda değişen tutumu, öncelikleri, sahip olduğu temel motivasyon ve bunların sonuçları -Türkiye'nin kendine özgü şartlarını dikkate alınarak- daha önce yapılan çalışmalar da incelenerek tartışılmaktadır. Son olarak çalışma değerlendirme ve sonuç bölümleri ile sona ermektedir.

\section{Kurumsal Girişimci Kavramı ve Liberal Sistemde Devlet Anlayışı}

İlk kurumsalcılık araştırmalarında (Selznick, 1957) aktörlerin eylemliliği açıklanırken, yeni kurumsal kuram çerçevesinde yapılan çalışmalarda aktörlerin kurumsal değişimdeki rolü göz ardı edilerek bunun yerine dışsal şokların etkisine odaklanılmıştır. Bunun üzerine, kurumsal girişimcilik kavramı, kurumsal değişimin içsel açıklamalarına yönelik yeni bir araştırma alanı olarak ortaya çıkmışır. 
Kurumsal girişimcilik yazını daha sonra katlanarak yaygınlaşmışıı. Kavramı, ilk defa Eisenstadt (1980) 'in "Cultural orientations, institutional entrepreneurs, and social change: Comparative analysis of traditional civilizations" adlı çalışmasından hareketle aktörlerin durağanlık yönündeki baskılara rağmen değişen kurumlara nasıl katkıda bulunabileceğini açıklama çabasıyla DiMaggio (1988) ortaya atmıştır. DiMaggio (1988) kurumsal girişimcileri mevcut kurumları dönüştürmeye veya yeni kurumlar yaratmaya katkıda bulunan değişiklikleri başlatan aktörler olarak tanımlanmıştır. Aktörün kurumsal süreçlerdeki rolünü inceleyen çalışmalar için bu tanım bir çıkış noktası oluşturarak kurumsal girişimcilik yazınının gelişmesine zemin oluşturmuştur (Maguire, Hardy \& Lawrence, 2004; Battilana, 2006; Garud, Hardy \& Maguire, 2007; Battilana, Leca \& Boxenbaum, 2009).

Bireyler veya birey gruplarının ya da örgütler veya örgüt gruplarının kurumsal girişimci olabileceğini ifade eden çalışmalar kurumsal girişimcilik yazınında yer bulmuştur (Leblebici, Salancik, Copay \& King, 1991; Fligstein, 2001; Greenwood, Suddaby \& Hinings, 2002; Kraatz \& Moore, 2002; Lawrence \& Phillips, 2004; Battilana, 2006). Hem bireylerin hem de örgütlerin kurumsal girişimci olarak yazında geniş ölçüde ele alınmalarına karşın, devletin kurumsal girişimci kimliğinin genel olarak ihmal edilmesi eleştirileri de beraberinde getirmiştir (Koç, 2013; Yalçınkaya \& Taşcı, 2020). İlginç bir biçimde bireyler, örgütler ve meslekler gibi mikro ve mezo düzeyde yapılan analizler ön planda iken, makro düzeyde devlet ve devletin kurumsal girişimciliği, dolayısıyla devletin kurumsal işleri ve farklı örgütsel alanlar ile ilişkileri araştırmalara konu edilmemiş görünmektedir. Amerikan siyasal sistemine ilişkin varsayımlar bu durumu bir nebze açılamaktadır. Ancak diğer ülkelerde devlete ilişkin fiili durum ve ona yüklenen anlamlar farklılaşmaktadır. Dolayısıyla yeni kurumsal kuram yazınında devletin adeta bir "kayıp parça" gibi durması, üzerinde düşünülmesi gereken özgün bir alan olarak ortada durmaktadır.

Yeni kurumsal kuram, devleti, örgütsel alanları rasyonelleştiren en önemli kurumsal girişimci olarak kabul etmektedir (DiMaggio \& Powell, 1991). Örgütsel alanlarda eylemde bulunan her aktör, elbette kurumsal girişimci kimliği taşımamaktadır. Ancak devlet, başlı başına farklı özellikler taşıyan bir örgüt ve aktör niteliğindedir. Devletin kurumsal girişimci kimliği liberal sistemde kısaca; kurumsal alanlarda örgütsel eylemler için firsatlar ve kısıtlar yaratan düzenleyici yapılar oluşturma kabiliyetine sahip, modern dünyada başat egemen, biçimsel örgütün doğumuna ve yayılımına katkıda bulunan, zorlayıcı ve normatif etkilere sahip, oyunun kurallarını belirleyebilen bir aktör olarak tasvir edilmektedir (Meyer \& Rowan, 1977; Fligstein, 1991; Palmer \& Biggart, 2002; Scott, 2003). 
Bir kurumsal aktör olarak devlete dair bu kabuller, devletin örgütsel yapıları ve uygulamaları şekillendiren koşulları belirleyebileceğini varsaymaktadır. Örneğin, Rowan (1982) tarafından yapılan bir çalışma, devlet tarafından sürekli olarak desteklenen bölge okullarındaki idari yapıların ve meslek örgütlerinin daha yaygın ve kalıcı olduğunu göstermektedir. DiMaggio (1983) da, federal hükümetin benimsediği politikalarla sergi merkezli müze modeline fon sağlayarak sanat müzelerinde benzeşmeye yol açtı̆̆ını ortaya koymuştur. Görüldüğü üzere bu çalışmalarda devlet, sosyal birimleri standartlaştırmak ve kontrol etmek için resmi örgütlenmenin ortaya çıkmasını ve yayılmasını etkileyen rasyonelleştirici ve benzeştirici bir aktör olarak resmedilmektedir (DiMaggio \& Powell, 1983).

Liberalizm, devleti girişimci ve yönetsel işlevlerle özdeşleştirirken ve firma modeline göre yeniden şekillendirirken, devletin demokratik bir kültür veya demokratik bir değerler tablosu içinde kabul edilemeyecek bir güç olma iddiasını kolaylaştırabilmekte ve meşrulaştırabilmektedir (Brown, 2006). Ayrıca, devletin demokratik yönetim anlayışını ve hesap verebilir oluşunu ve bu sayede üzerindeki kısıtlamaları etkinlik veya karlılık gibi iyi yönetim normlarıyla değiştirmektedir (Brown, 2006). Öte yandan devletin kritik bir kurumsal değişim kaynağı olduğu ve örgütsel eylemler için firsatlar ve kısıtlar yaratan düzenleyici yapılar kurduğu da ifade edilmektedir (Palmer \& Biggart, 2002). Bu açıdan devlet, sahip olduğu zorlayıcı ya da normatif güç sayesinde örgütleri daha etkili ve verimli olduğu düşünülen yeni örgütsel biçimleri ve uygulamaları benimsemeye yönlendiren aktör olarak resmedilmektedir. Devlet, rasyonalleştirme yolu ile sosyal kontrolü geliştirecek gerekli önlemleri tutarlı bir şekilde almaktadır. Bu nedenle, liberal sistem olarak ABD'de, devlet genel olarak, oyunun kurallarını tasarlayıp uygulayabilen ve örgütlerin davranışlarını toplumda baskın olan ekonomik ve politik ideolojilerin ifade şekilleri haline getirerek meşrulaştıran bir aktör olarak görülmektedir (Fligstein, 1990).

ABD'deki liberal devletin bir başka özelliği de kurumsal/örgütsel alanlara karşı konumuna ilişkin olarak ortaya çıkmaktadır. ABD kurumsal bağlamı dikkate alınarak yapılan çalışmalarda devletin örgütsel alanlarda doğrudan bir katılımcı olmadığı, fakat herhangi bir örgütsel alan için oyunun kurallarını belirleyebildiği savunulmaktadır. Ayrıca devletin, örgütler arasında arabuluculuk yapabildiği ve dengeyi sağlamak için tüm örgütlerin çıkarlarına uygun davranmaya çalıştığ 1 ifade edilmektedir. Ancak bu durumun devletin belirli bir alandaki diğer aktörlerden daha güçlü olduğu anlamına gelmediği vurgulanmaktadır (Fligstein, 1991).

İktisat, siyaset bilimi ve kamu yönetimi alanlarında devlet kavramı tartışmaları, devlet aygıtındaki ve işlevindeki değişimler, farklı toplumsal kesimler ile devletin 
ilişkilerinden hâkim siyasal söylemlere, kapitalizmin krizleri ve gelişim süreçleri ile ulus devletin küreselleşme karşısındaki konumuna kadar çok geniş bir yelpazede devam edegelmektedir. Devlet tanımlamalarında, devletin oynadığı rollerdeki değişkenliğin ve kamu reformlarının açıklanmasında, ekonomik krizler ya da genel olarak kapitalizmin krizleri ile bağlantıların altı çizilmektedir (Akçay, 2013). Kapitalist toplumsal ilişkiler içerisinde devleti konumlandırabilmek için başlangıçta devletin ne anlama geldiğine ilişkin ön kabullerin belirgin hale getirilmesi gerekmektedir. $\mathrm{Bu}$ bağlamda öncelikle ifade edilmesi gereken, liberal ve devlet odaklı kurumsalcı perspektiflerin ve bunların farklı versiyonlarının sahip olduğu ortak bir özellik olarak devlet ile toplumun (ekonomi ile siyasetin) birbirinden bağımsız birer toplumsal gerçeklik olarak tanımlanmasının devletin gerçekte ne olduğunun anlaşılmasını kolaylaştırmaktan ziyade zorlaşıtıdığıdır. Bunun en önemli nedeni, her iki yaklaşımda da devletin toplumun dışında ve üstünde, ya ona müdahale eden ya da tarafsız bir şekilde ondan etkilenen bir konumda kavramsallaştırılmasıdır (Akçay, 2013). Diğer bir deyişle devletin mevcut kurumları dönüştürmesinin, ortadan kaldırmasının, yeni kurumlar ve kurumsal alanlar yaratmasının, kapitalist sistemdeki değişimlerden, krizlerden ve uluslar arasında çeşitlenen kapitalist sistemlerden ayrı düşünülmesi sorunlu bir izleğe yol açmaktadır. Neoliberal söylemle birlikte eylem ve uygulamalarda politik olanla iktisadi olanın birbirinden yalıtıkmış gibi konumlandırılması, devlet kavramı özelinde eksik bir kavrayışa yol açmaktadır.

Yeni kurumsalcılık bağlamında Kuzey Amerika’da yapılan çalışmalar, daha çok devlet ve ekonomi ikiliğinden hareket eden ve devletin ekonominin gereklerinden ya da daha özel olarak toplumsal sınıfların taleplerinden bağımsız hareket etme kabiliyetinin olduğunu varsayan (Akçay, 2013) bir yaklaşım üzerine inşa edilmiştir. Özen (2014), Anglo-Amerikan bağlamındaki yeni kurumsalcı çalışmalarda izlenen devlet kavramlaştırması ve rollerini "(1) Devlet, toplumdaki baskın ideolojiler ile uyumlu bir şekilde oyunun kurallarm belirleyebilen ve bu kuralları uygulayabilen; (2) kurumsal/örgütsel alanların dı̧ıında ve çatışan çıkarları olan aktörlerin arasında arabulucu pozisyonda olan bir aktördür; (3) ve devlet, kurumsallörgütsel alanlarda planlanan istikrarın ve değişimin ana kaynağrdır" biçiminde özetlemektedir. Buna göre, siyaset ve siyasa özelliklerinin ülkeler arasında farklılık gösterdiği gerçeği göz önüne alındığında, yeni kurumsal kuramın, tam olarak liberal politik özellikler taşımayan ülkelerdeki örgütsel gerçeklikleri açıklamakta zayıf kaldığı öne sürülmektedir (Özen, 2014). Sonuç olarak, liberal devlet kabullerine dayanan varsayımların ve devlet kavramsallaştırmasının yapılacak yeni araştırmalar ve tartışmalar ile tadil edilmesi, farklı bulgular ile daha açıklayıcı bir çerçeveye kavuşturulması ihtiyacı açıktır. Yeni kurumsalcı kuramın temel varsayımları kısa dönemde değişmese de, 
farklı bağlamlarda devletin kurumsal girişimci rolüne ve kurumsal işlerine ilişkin olarak yapılacak görgül çalışmalar ve tartışmalar, temkinli bir yaklaşımla, kuramın açıklayıcı gücünü geliştirmeye yardımcı olabilecektir.

\section{Siyasa Farklılıkları ve Değişen Devlet Kavramsallaştırmaları}

Yeni kurumsal kuramın devleti bir kurumsal aktör olarak liberal sistem varsayımları altında kavramlaştırması, siyasal sistem ve bağlam farklılıklarını göz ardı etmesi, devletin kurumsal süreçlerdeki rolünün eksik biçimde kavranmasına yol açmaktadır (Tempel \& Walgenbach, 2007). Jepperson ve Meyer (1991) yaptıkları çalışmada siyasal sistem farklılıklarının kurumsal süreçler üzerindeki etkisini incelemişler ve devletlerin sahip oldukları siyasal sistem farkl11klarının "sosyal birimlerin kamusal aktör olarak yetkilendirilme derecesi ve kamusal işlevlerin kolektif olarak kurumsallaşma derecesi” olmak üzere iki ana boyutta ortaya konabileceği belirtmişlerdir. Burada bahsedilen ilk boyut bireysel aktörlerin elinde bulundurduğu iktidar gücünü ve bu gücü toplum adına kullanma hakkına sahip olmasını ifade etmektedir. Bu sistemde kamusal ve özel alanlar birbirinden keskin bir biçimde ayrıştırılmamıştır. Diğer boyut ise, siyasal sistemin tüm görevleri ve fonksiyonel bağlantıları ne derece doğrudan belirlediği ve kontrol ettiği ile ilgilidir. Bu çerçevede farklı siyasal sistemler "liberal, devletçi, korporatist ve bölünmüşsistemler" olmak üzere dört farklı isimle kategorize edilmiştir. Tablo 1 bu boyutları ve siyasal sistemleri göstermektedir (Jepperson \& Meyer, 1991):

Tablo 1. Siyasal Sistemler

Kamusal İşlevlerin Kolektif Olarak

Kurumsallaşma Derecesi

\begin{tabular}{|c|c|c|c|}
\hline \multirow{3}{*}{$\begin{array}{l}\text { Sosyal Birimlerin } \\
\text { Kamusal } \\
\text { Aktör Olarak } \\
\text { Yetkilendirilme }\end{array}$} & & & \\
\hline & Yüksek & Liberal/Bireyci & Devletçi \\
\hline & Düsük & $\begin{array}{c}\text { Bölünmüş (Toplum dişında } \\
\text { devlet) }\end{array}$ & Korporatist \\
\hline
\end{tabular}

Kaynak: Jepperson ve Meyer (1991)'den uyarlanmıştır. 
Liberal sistemde hâkim olan devlet anlayışının farklı sistemlerdeki devlet kavramlaştırmasını doğru bir şekilde yansıttığını söylemek mümkün değildir. Örneğin, liberal sistemlerin etkin olduğu Anglo-Amerikan ülkelerinde kurumsal değişimin başat aktörü genellikle çeşitli çıkarlara sahip toplum kesimleri olmakta iken, devletçi sistemlerin baskın olduğu ülkelerde değişimin birincil aktörü olarak devlete işaret edilmektedir (Jepperson \& Meyer, 1991).

Liberal sistemde bireyler, çıkarları ve tercihleri toplumun büyük bir kesimi tarafından meşru kabul edilen egemenliğe sahip ve bu egemenliği kullanabilecek kapasitede sosyal aktörler olarak kabul edilir ve devletin toplumsal/kurumsal alanlara müdahalesi sınırlı düzeyde gerçekleşir. Bu sistemde devlet kurumsal alanların dışında, alanlara doğrudan müdahale etmeyen ve daha çok alanın kurallarını belirleyen bir kurumsal aktör olarak kavramsallaştırılır. Devlet/toplum ayrışmasının devletçi sisteme nazaran keskin şekilde oluşmadığı liberal sistemde güç toplumsal kesimlerde yoğunlaşır. Bireylerin toplumu meydana getiren kamusal varlıklar olarak görülmesi sonucu, çlkarlar toplumsal/kurumsal alanlarda etkin bir şekilde dile getirilir ve bu sistemde her bir çıkarın savunulması için biçimsel örgütlenmenin oluşturulmasını zorlayan bir devlet müdahalesi görülmez (Jepperson \& Meyer, 1991).

Anglo-sakson gelenek ve çok genel hatları ile liberal siyaset ve devlet anlayışının dışında kalan coğrafyalarda ve devletçi siyasal sisteme sahip ülkelerde devlet, genel kamu çıkarının belirlendiği ve en akılcı yapının oluşturulduğu yerin adresidir (Jepperson, 2002; Jepperson \& Meyer, 1991). Bu sistemde devlet, toplumdan özerk olarak bulunur ve müdahalesi ile kurumsal alanlarda etkinlik sağlar. Örneğin, Doğu Asya ülkeleri Güney Kore ve Tayvan'ın ekonomik başarısı, devletin tutarlı ve istikrarlı uzun vadeli sanayileşme hamlelerini kararlılıkla sürdürmesi, ekonomide belirsizliği azaltıcı rol oynaması ve bu ülkelerin girişimcilerini rant ve spekülatif faaliyetlere yönlendirmemesi ile açılanmaktadır (Buğra, 1994). Bu ülkelerde devletin piyasayı geliştirici rolünün aksine Türkiye'de aynı özerkliğe sahip devlet, yaptığı müdahalelerle ekonomik hayatı derinden etkileyen bir belirsizlik kaynağı olarak görülmektedir (Buğra, 1994; Özen, 2010).

Jepperson ve Meyer (1991) modelinde devletçi tipolojiye benzer özellikler gösteren Türkiye, tam olarak burada belirtilen nitelikleri de taşımamaktadır. Bu şartlar altında hem "sosyal birimlerin kamusal aktör olarak yetkilendirilme derecesi" ve hem de "kamusal işlevlerin kolektif olarak kurumsallaşma derecesi" açısından düşük profil sergileyen bölünmüş devlet/toplum tipolojisi ön plana çlkmaktadır. 
Bu koşullarda Türkiye bağlamında devleti "devletçi” kategoride tanımlamak daha zor görünmektedir.

Türkiye’de devlet, kendine özgü öncelikleri, patrimonyal yapısı ve kamu politikalarını uygulamadaki kapasite eksikliği ile liberal sistemden tamamen, devletçi siyasal sisteme sahip ülkelerden ise kısmen farklı bir şekilde karşımıza çıkmaktadır (Özen \& Özen, 2009; Özen, 2011). Türkiye bağlamında devlet, kurumsal alanların dışında değil içinde bir aktör olarak bulunmakta, rasyonelleşme yerine belirsizlik ve çeşitliliğe, eksik kurumsallaşmaya ve değişim yerine törensel benimsemeye neden olmaktadır (Özen, 2014; Özen, 2011).

Devletçi sistemlerde liberal sistemden farklı olarak değişen bu devlet anlayışının Türkiye'deki kurumsal süreçlerde nasıl ortaya çıktığı ve hangi sonuçları yarattığı, yapılan akademik çalışmalara da yansımıştır. Türkiye'de özellikle son kırk yıllık süreçte uygulanan liberalleşme politikaları gücün ve egemenliğin bireylere ve toplum kesimlerine yayılmasını sağlamamış, güç ve egemenlik kurumsal süreçlerde söz sahibi devlette ve yönetici elitlerde toplanmıştır (Özen \& Akkemik, 2012). Türkiye'de topluma yukarıdan aşağıya yön veren, toplumdaki farklı çıar gruplarına mesafeli olan ve toplumu kendisini sınırlayan ve rasyonel olmayan bir yapı olarak niteleyen bir devlet kavramlaştırılması oluşmuştur (Özen \& Özen, 2009). Türkiyede devlet, toplumdan belirgin biçimde ayrışan ve sahip olduğu aygitlar ile birleşik bir organizasyon olarak resmedilen devlet anlayışına göre değerlendirildiğinde; örgütlenmemiş ve aktif olmayan topluma kendi düzenini ve kurallarını dikte edebilen, toplumsal ilişkilere hâkim, kurumsal alanların içinde ve bu alanlarda en güçlü pozisyona sahip (buna rağmen kamu politikası yapma kapasitesi düşük), jakoben özellikleri bünyesinde barındıran (Gourisse, 2016) bir kurumsal aktör olarak görülmektedir. Kısaca, Türkiye'de devletin, bir kurumsal girişimci olarak en güçlü pozisyona sahip olmasına ve istediği kaynaklara rahatça erişebilmesine rağmen, kurumsal alanları istikrarlı bir şekilde kurumsallaştırma ve bunun sürekliliğini sağlama gibi tipik sonuçlar üretebildiğini söylemek güçtür. Dolayısıyla Türkiye'de devletin, kendine özgü koşullarda şekillenen farklı tercihleri ile kurumsal alanlar ve örgütler açısından farklı sonuçlar üreten bir eylemsel çeşitliliğe sahip olduğunu düşünmek mümkün görünmektedir.

\section{Türkiye'de Bir Kurumsal Girişimci Olarak Devlet}

Türkiye'deki devlet ve aygıtları ile toplum grupları arasındaki ilişkilerin nasıl geliştiğinin ve ne yönde seyrettiğinin bilinmesi, içinde bulunulan bağlamın ve bu 
bağlamdaki kurumsal aktörlerin davranışlarının anlamlandırılması adına son derece önemlidir. Türkiye’de devletin kurumsal bağlamın birincil aktörü olarak (Dirlik, 2016) kurumsal değişimlerde belirleyici olduğu ifade edilebilir. Türkiye'deki politik yapının devletçi korporatist, neo-korporatist ve çoğulcu sistemlerden herhangi biri olamayacağını, fakat tekilci (monist) sayılabileceğini savunan Heper (1991), iddiasını güçlendirmek için “devletlilik” (stateness) kavramını ortaya atmışır. Devletlilik kavramı, politik sistemdeki devlet geleneğine sadık olan çeşitli çıkar gruplarının benimsediği farklı siyasi anlayışların/ideolojilerin belirgin bir model etrafında şekilleneceği iddiasını savunmaktadır. Heper (1991), Türkiye'de devletin sürekli bir şekilde sivil toplumu oluşturan kesimlerin çıkarlarını yok sayabilen, bu anlamda herhangi bir sorumluluk hissetmeyen, nobran bir yönetim tavrı sergilediğini, toplumdaki farklı çıkar grupları ile "pederşahi” ilişkiler kurduğunu ve patrimonyalist bir toplum yapısı oluşturduğunu öne sürmektedir. Benzer şekilde, Buğra (1994) da, hakim siyasal sistem etrafında çeşitli çıkar gruplarının şekillendiğini, devlet ile sivil toplum arasında dengeli bir ilişkiye dayanan Avrupa tarzı yeni korporatizmin Türkiye bağlamında gerçekleşmesinin neredeyse imkansız olduğunu dile getirmekte ve bunun nedeninin de geçmişten gelen Türk devlet geleneği olduğunu belirtmektedir. Siyasal sistem değişiminin daha farklı bir yolla olabileceğini ifade eden Özen (2011), var olan devlet geleneğinin güncel politik gelişmelerin etkisi ile günü birlik oluşturulan (oluşturulmaya çalışılan) sistemlerin aynı anda görüldüğü bir "çeşitliliğin" varlığı ile açıklanabileceğini belirtmektedir (Özen, 2011). Diğer bir deyişle, Türkiye'de devlet/toplum ilişkilerinde baskın bir politik sistem yerine, bazen ulus-devlet geleneğinin yansımalarının, bazen devletçi korporatizmin etkilerinin, bazen de liberalleşmenin getirdiği uygulamaların ve etkilerin aynı dönemde görülmesinin mümkün olduğu ifade edilmektedir (Özen, 2011).

Türkiye'de devlet sadece kurumsal alanlar/yapılar oluşturan bir aktör değil, aynı zamanda ekonomik bir aktör olarak piyasalara müdahale eden, ekonomik kalkınmada öncü rolleri olan baskın kalkınmacı bir girişimci olarak da görülebilir (Whitley, 2005). Bu doğrultuda Buğra (2013), ekonomik başarının açiklanmasında "devletin özerkliği" ve "devlet kapasitesi" kavramlarının etkin bir rol oynadığını öne sürmektedir. Devletin, toplumsal grupların çıkarlarından bağımsız karar alma ve bu çıkarlardan bağımsız hareket edebilme kabiliyeti özerklik olarak tanımlanırken, alınan kararları uygulamada sahip olduğu örgütsel imkanlar ise kapasite olarak ifade edilmektedir (Buğra, 2013). Bu kavramları referans alarak devletlerin toplumları belirli amaçlara yönlendirme gücünü açılkayan Skocpol (1985) devletin, "yönetim, polis ve ordu” organizasyonlarının birleşimden teşekkül ettiğini ve gücünü kendi 
kurumlarından aldığını belirtmektedir. Ancak Türkiye’de devletin, bu özerkliğe sahip olmasına rağmen kamu politikaları oluşturma ve uygulama anlamında düşük kapasiteye sahip olması, ekonomide başarılı olmaktan ziyade belirsizlik kaynağı olarak görülmesine neden olmaktadır (Buğra, 1994).

Elbette, Türkiye'de devlet kavramı üzerine düşünmek, coğrafyanın tarihsel arka planı, siyaset ve ekonomi geleneklerinin süregiden nitelikleri kadar, günümüz kapitalizminin çeşitliliği, krizleri ve küresel neoliberalleşme süreci ile de ilintilidir. Tüm dünyada 1980'lerden bu yana net biçimde görünür hale gelen neoliberal politikalar, Türkiye'de de devlet aygıtının dönüşümünü başlatmıştır. Buna bağlı olarak otoriter devlet formunun ana bileşenleri olarak tanımlanan eğilimler bu süreçte daha açık ve yaygin hale gelmiştir (Oğuz, 2012).

Sonuç olarak, 2000'li yıllarda Türkiyede ülkenin global rekabet gücünü artırmak amacıyla uygulana politikaların iki genel sonuç doğurduğu belirtilmektedir: Bunlardan ilki gücü üzerindeki kontrol mekanizmalarının çeşitlenmesi, ikincisi ise sermaye-içi çelişkilerin bölge ve sektör temelinde daha da farklılaşarak karmaşıklaşmasıdır. Bu durumun, neoliberal otoriter devlet formunun yeni mekanizmalarla pekiştirilmesini beraberinde getirdiği öne sürülmektedir (Oğuz, 2012). Bu çerçevede, devletin farklı kurumsal alanlarda oynadığı kurumsal girişimci rolünün ve kurumsal işlerinin de bu makro perspektif göz önüne alınarak çözümlenmesini sağlayacak farklı yaklaşımlara ihtiyaç doğmaktadır. Türkiye bağlamında yapılan çalışmalar incelendiğinde, Türkiye'de devletin bir kurumsal aktör olarak kurumsal alanlarla ilişkisinin değişkenlik gösterdiği dikkat çekmektedir. Türkiye bağlamına ilişkin araştırmalar, eğitim, sağlık, sosyal sigorta, meslek örgütleri, futbol (Taş \& Hızıroğlu, 2016; Özseven, Danışman \& Bingöl, 2014; Özseven, Danışman \& Bingöl, 2016; Türkeli, 2012; Gökoğlu, 2012; Özkara \& Özcan, 2004; Koç, ÖzenAytemur \& Erdemir, 2016) vb. alanlarda devletin müdahalelerini, diğer bir deyişle kurumsal girişimci olarak yürüttüğü kurumsal işleri ortaya koymaktadır. Buradan iki sonuç çıkarmak mümkündür: Öncelikle devletin müdahale biçimi söz konusu alanlarda farklılık göstermektedir. İkinci olarak da bazı alanlarda devletin hemen hiç müdahil olmadığı ve bunun üzerinde hemen hemen hiç durulmadığı gözlemlenmektedir. Burada göze çarpan söz konusu değişkenlik, sürekli müdahil olma, belirli koşullarda (pragmatik veya konjonktürel gerekçelerle) düzensiz müdahalelerde bulunma, hiç müdahil olmama gibi devlet eylemleri, bir kurumsal girişimci olarak devletin durumu hakkında sorular sormaya elverişli bir zemin yaratmaktadır. Kavramsal olarak, tarafsız, liberal devlet kabulünün veya varsayımının karşısına, her alana müdahil bir devlet eylemliliği koymak da mümkün görünmemektedir. Bunun 
yerine, çeşitli kurumsal alanlarla ilişkisi ve eylemliliği de çeşitlenen bir kurumsal aktör olarak devlet kavramsallaştırması, Türkiye bağlamı için daha açıklayıcı bir çerçeve sunmaktadır. Diğer bir deyişle, Türkiye bağlamında devlet, ABD-Anglo Sakson geleneğinde resmedilen devlet tahayyülünün tam karşısında da yer almamaktadır. Yani liberal sistemden farklı olarak Türkiye'de devlet her alana müdahil, her alanda istikrarsızlık yaratan bir başka "taraflı/yekpare" kurumsal aktör davranışı sergilememektedir. Burada bir karşıtlıktan ziyade bir davranış/eylem çeşitliliğinden söz etmek mümkündür.

Buradan hareketle, kurumsal bir aktör olarak devletin temelde sahip olduğu motivasyon ile kurumsal alanların özelliklerini ilişkilendirerek devletin değişen eylem tipolojilerini farklı bir şekilde tanımlamak mümkün görünmektedir. Yukarıda belirtilen Türkiye'ye özgü devlet ve siyasal sistem tartışmalarından yola çıarak, bir kurumsal aktör olarak devletin kurumsal alanlarla ilişkisi iki temel amaca dayandırılmaktadır: (1) toplum üzerinde kontrol sağlama ve (2) kaynaklarn (siyaseten) yeniden dağıtma.

Toplum üzerinde kontrol sağlama, Türkiye'deki devlet geleneğinin önemli ve tarih boyunca pek değişkenlik göstermeyen bir ana karakteristiği olarak karşımıza çıkmaktadır (Heper, 1991). Kaynakların devlet eliyle yani siyaseten yeniden dağılımını sağlamak, Türkiye gibi kapitalizme geç entegre olmuş devletlerde gözlemlenen özelliklerden birisidir (Buğra \& Savaşkan, 2015). Öte yandan, neoliberal iktisadi politikaların hakimiyeti, Türkiye'nin bu küresel dönüşüm sürecine entegrasyonu ve birçok gelişmiş ve gelişmekte olan ülkede yükselen yeni muhafazakar politikalarla birlikte dönüşen devlet aygıtı (Brown, 2006; Brown, 2010; Buğra \& Savaşkan, 2015; Akçay, 2013; Oğuz, 2012; Mollaer, 2016) çeşitli toplumsal kesimler arasında sermayenin aktarımını sağlayan, küresel rekabete katılımı kolaylaştıran, devletin iktisadi rolünü yeniden tanımlayan temel belirleyici olarak ortaya çıkmaktadır. Dolayısıyla Türkiye'de devletin çeşitli kurumsal alanlardaki eylemliliğinin, bu iki saikten bağımsız düşünülmesi, örgütsel alanlara ilişkin gelişmeleri (yeni alanların doğuşu, örgütsel formlar, kurumsal pratikler, aktörler vb.) açıklama çabasında eksik bir kavrayışa yol açacaktır.

Buna göre, Türkiyede kurumsal alanların toplum üzerinde kontrol sağlama ve kaynakların yeniden dağılımına imkân verme potansiyeline göre taşıdığı özellikler, devletin farklı alanlara göre çeşitlenen eylemliliğini, dolayısıyla kurumsal işlerini belirleyebilecektir. Diğer bir deyimle, Türkiye'de devlet, kendisine ait iki temel saik ile ilişkilendirerek "seçtiği”" farklı kurumsal alanlarla farklı ilişkiler kurması sonucunu 
doğuran bir eylemsel çeşitliliğe sahip olabilecektir. Bu açıdan devletin, ne liberal varsayımlarla uyumlu biçimde bütünüyle tarafsız, rasyonel ve alanların dışında, ne de tüm kurumsal alanlara müdahil ve irrasyonel kabul edilmesi mümkündür.

Alandaki kuramsal tartışmalardan ve Türkiye'de devletin kurumsal girişimci rolleri üzerine yapılan araştırmalardan yola çıkılarak, devletin söz konusu eylemsel çeşitliliğine ilişkin iki boyutlu bir hipotetik model ortaya konulmuştur. Söz konusu model, toplumu kontrol etme ve kaynakların yeniden dağılımını sağlama amacı ile değişen kurumsal alanlarda "görmezden gelme, dönemsel-pragmatik müdahale etme, alana dahil aktör olarak sürekli müdahale etme ve çelişkili-sürekli müdahale etme" şeklinde dört farklı kurumsal iş tipolojisi önermektedir (Şekil 1).

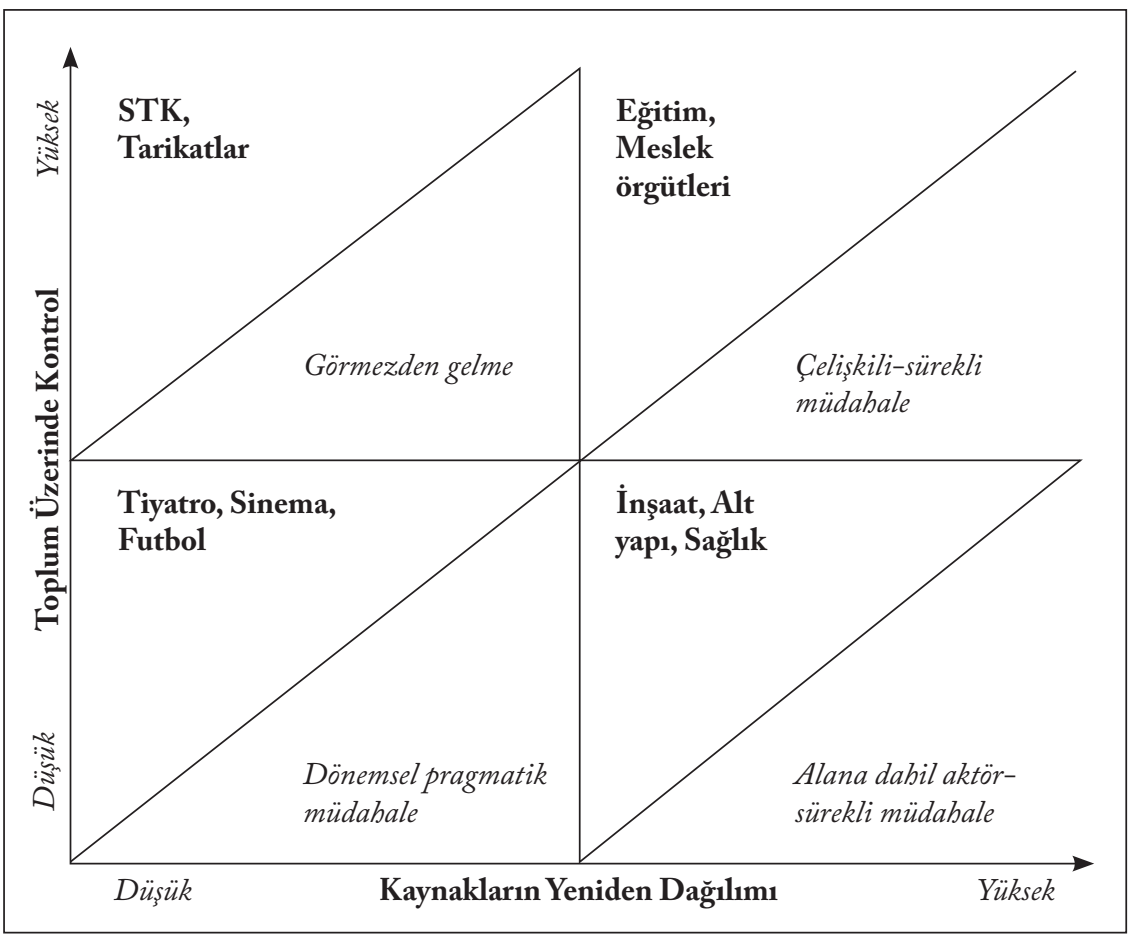

Şekil 1. Bir Kurumsal Aktör Olarak Devletin Eylemlerine İlişkin Olası Tipolojiler

İlk olarak, devletin düzenleme ve rasyonelleştirme saiki ile müdahale etmediği ancak toplum üzerinde kontrol sağlamak amacına hizmet etme potansiyeli bulunan oluşumlara ve bunların faaliyetlerine duyarsız kaldığı, önemli ölçüde bir 
"görmezden gelme" eylemi benimsediği alanlara örnek olarak sivil toplum kuruluşları verilebilir. Politik alanın, diğer bir deyişle devlet hakimiyetinin bulunduğu alanın dışında toplumun faydasına çalışan, herhangi bir kar kaygısı taşımayan Sivil Toplum Kuruluşlarının (STK) Türkiye bağlamında değerlendirildiğinde yönetimde karar alma bakımından etkin konumda bulunduklarını söylemek pek mümkün görünmemektedir (Yılmaz, 2018; Bulut, Akın \& Kahraman, 2017). Liberal devlet anlayışında önemli bir yere sahip olan sivil toplum kuruluşları, amaçları, faaliyetleri ve devlet ile ilişkileri açısından önemli bir çeşitliliğe sahiptir. Türkiye’de 1980 sonrası farklı iç ve dış faktörlerin etkisiyle faaliyetleri ülke geneline yayılmış STK'lar, toplumsal değişimin önemli aktörleri haline gelmişlerdir (Ertugay, 2013). Türkiye'de STK - Kamu (Devlet) işbirliğini düzenleyen yasal bir mevzuat bulunmadığından STK'lar ve devlet arasında etkin bir işbirliği sağlanamamakta ve buna bağlı olarak STK'lar politika oluşturma sürecinde bir paydaş olarak görülmemekte ve devlet tarafından görmezden gelinerek karar alma süreçlerine dahil edilmemektedir (Bulut vd., 2017). Kısaca, Türkiye'de devlet, sivil toplum alanını düzenlemek için gerekli yasaları çıkarmayan ve mevzuatları oluşturmayan, buna bağlı olarak STK'ların özerkliğini sağlayacak adımları atmayan ve onları kendi çıkarları için finanse eden, ihtiyaç duyduğunda toplum üzerinde bir kontrol aracı olarak kullanan eylemler sergilemektedir (Şahin \& Uysal, 2007).

Öte yandan, Cumhuriyetin ilanı ile birlikte laikliğin benimsendiği Türkiye'de tekke ve zaviyeler, misyonunu tamamladıkları, eğitici yönlerini kaybettikleri, yeniliğin ve modernliğin önünde engeller oluşturdukları düşüncesiyle 13 Aralık 1925 tarihinde 677 sayılı kanunla kapatılmışlar, buna rağmen birçoğu bir şekilde faaliyetlerine devam etmişlerdir (Ayık, 2016; Dağ \& Kılıç, 2019). Türkiye'de ulus-devletin kurulması ile birlikte vatandaşlık temelinde yeni bir siyasal ve sosyal yapı oluşturulmaya çalışılmıştır. Kentleşmenin artması ve 1980 ve sonrasında liberalleşme çabaları ile kendilerini ifade etme şansı bulan tarikatlar/cemaatler yetiştirdikleri kadroları ile medya kuruluşları, okullar, üniversiteler, hastaneler açarak (Efe, 2017) kurumsallaşmışlar ve büyük bir sermaye ve insan kaynağı gücüne sahip olmuşlardır. Devletin çoğunlukla görmezden geldiği bu dini yapıların bu kadar büyümesi ve toplumda karşılık bulması devletin kendileri ile çeşitli ilişkiler geliştirerek toplumu kontrol etmek için bir araç olarak kullanmasını kolaylaştırmıştır (Saymaz, 2019).

Diğer yandan, Türkiyede devletin bazı alanlarda toplumu kontrol altında tutma veya kaynakların yeniden dağılımını sağlama saikleri ile hareket etmek yerine daha çok dönemsel ve pragmatik müdahalelerde bulunduğu gözlemlenmektedir. Bu alanlarda devlet, dönem dönem ve kısmi müdahalelerde bulunan bir rol 
oynamaktadır. Bu kurumsal alanlara örnek olarak tiyatro, sinema ve futbol alanları verilebilir. Cumhuriyet'in ilk yıllarından itibaren birçok alanda başlayan yeni yapılanma süreci Türk tiyatro alanında da kendisini hissettirmiştir. Siyasal, ekonomik ve kültürel değişime bağlı olarak Türk tiyatro alanı da ulusal tiyatro ve halk yararına halk tiyatrolarının kurulması ile gelişim sürecinden etkilenmiştir. Bu dönemde tiyatronun bir kamu hizmeti olduğu ve devlet tarafından korunması ve desteklenmesi gerektiği üzerinde durulmuştur (Erkoç, 1995). Cumhuriyet' in ilk yıllarında devlet, tiyatroyu toplumu yenilemek (modernleştirmek) için bir güç olarak kullanmıştır (Öz \& Belkıs, 2017). Çok partili sisteme geçilmesi ile birlikte devletin yeni yöneticilerinin benimsedikleri ideolojik görüşlere bağlı olarak Türk tiyatro alanında devletin kurumsal girişimciliği zayıllamışır (Birkiye, 2012). Genel bir bakışla tiyatro sanat alanında yaşanan gelişmeler devletin tiyatro sanat alanında dönemsel ve pragmatik şekilde hareket ettiği biçiminde yorumlanabilir (Savut, 2014).

Devletin benzer motivasyon ile hareket ettiği, diğer bir ifade ile kaynakların yeniden dağılımı veya toplum üzerinde kontrol sağlama amacına düşük düzeyde destek veren dönemsel ve pragmatik müdahalelerde bulunduğu kurumsal alan olarak sinema ve futbol alanlarını da göstermek mümkündür. Örneğin, Kalemci ve Özen (2011) Türk sinema alanına ilişkin olarak yaptıkları çalışmada alanın kurumsal alt yapısının az sayıdaki yerli aile şirketlerinin çabaları ve güçlü birkaç yabancı şirketin yaptığı yatırımlar aracılığı ile oluşturulduğunu, devletin alanda sansür mekanizmasını uygulamak dışında sessiz kaldığını ortaya koymaktadırlar (Kalemci \& Özen, 2011). Aynı şekilde Türk futbol alanında da ilk zamanlarda (1900’lü yıllar) devlet futbol alanına ilgi göstermemiş, daha sonra değişik dönemlerde farklı biçimlerde alana dönemsel ve pragmatik müdahalelerde bulunmuştur (Emrence, 2010). Devletin ilk zamanlar futbola ilgi göstermemesinin sebebi olarak siyasi istikrarsızlık, gayrimüslimlerin futbola daha çok ilgi duyması ve kültürel olarak genel anlamda toplumun değerlerine futbolun uygun düşmemesi gösterilebilir (Koç, ÖzenAytemur \& Erdemir, 2011). Sonraki dönemlerde ise zaman içinde değişen etkisine rağmen devletin Türkiye'de futbol alanında en önemli aktörlerden biri olduğu belirtilmiştir. Gerçekten de, devlet, dönem dönem futbol kulüpleri kurup yönetmiş, hangi kulübün şampiyon olacağına karar vermiş ve özerklik hakkına sahip düzenleyici kurumlar oluşturmuştur ( Koç vd., 2016).

Önerilen devlet eylemleri tipolojisi içinde üçüncü olarak, hem yüksek düzeyde toplumu kontrol etme veya biçimlendirme potansiyeli taşıyan hem de kaynakların yeniden dağılımına imkân veren alanlarda gözlemlenen "çelişkili-sürekli müdahale" biçimi yer almaktadır. Devletin "amacının” ilginç biçimde aynı kaldığı, ancak 
söylemini ya da gerekçelerini değiştirerek sürekli müdahale ettiği kurumsal alana tipik bir örnek olarak Türk milli eğitim alanı verilebilir. Milli eğitim alanında yapılan çalışmalarda, özellikle Cumhuriyet'in kuruluşundan sonra ulus-devletin güçlendirilmesi, yurttaş bilinci yaratma, ortak kültür birliğini kurma, ihtiyaç duyulan insan kaynağını yetiştirme gibi amaçları gerçekleştirme adına eğitim alanındaki faaliyetleri, devletin alanda (alanın içinde konumlanarak) tek aktör olarak yürüttüğü görülmektedir (Şimşek, Küçük \& Topkaya 2012; Taş \& Hızıroğlu, 2016). Türk Milli Eğitim alanında Cumhuriyet'in ilk yılları dışında (çok partili dönem ve sonrasında) devletin kararlı ve tutarlı biçimde yönlendirdiği kurumsal değişimlerden söz etmek güçtür. Geleneksel olarak ideolojik anlamda bölünmelerin yaşandığı devletlerden (Mardin, 1992) biri olan Türkiye’de Kemalizm’den İslamcılığa uzanan, farklı siyasi görüşlerin çerçevelendirdiği devlet politikaları (siyasa farklılıkları) kurumsal alanlarda da kendisini göstermiştir. Devlet politikalarındaki farklılığın ya da diğer bir deyişle siyasa farklılıklarının belirgin olarak görüldüğ̈̈ Türk milli eğitim alanında devlet, toplum üzerinde kontrol sağlama ve ulus-devlet inşası, yurttaş bilinci oluşturma, makbul vatandaş yetiştirme, kültür birliği sağlama vb. amaçları gerçekleştirme yolunda alana birbiriyle zaman zaman çelişkiler sergileyen müdahalelerde bulunmuştur. Bu nedenle, devletin yeni kurumsal kuram varsayımları altında belirtilen kurumsal alanları rasyonelleştirici ve benzeştirici rolünün varlığından söz etmek mümkün görünmemektedir. Bilakis, Türkiye örneğinde farklı siyaset/siyasa anlayışları ile sürekli müdahale edilen milli eğitim alanında devlet, eksik kurumsallaşmaya, belirsizliğe ve çeşitliliklere neden olmuştur (Taş \& Hızıroğlu, 2016).

Öte yandan, 1980 sonrası dönemde özel okulların desteklenmesi ile birlikte, geleneksel olarak kamusal karakteri baskın olan eğitim alanı büyük oranda piyasalaştırılmıştır. Özel okullar teşvik edilmiş, aileler bu kurumlara yönlendirilmiş ve büyük bir piyasanın doğması devlet eliyle sağlanmıştır. 1980'li yılların ortalarında Türkiye genelinde özel okul sayısı 300 iken özel okulların devlet tarafından teşvik edilmesi ile bu sayı 2000'li yılların başında 1780 sayısına ulaşmıştır (Uygun, 2003). Tümüyle kamusal kaynaklarla desteklenmemekle birlikte, yapılan düzenlemeler, yönlendirmeler ve teşviklerle birlikte özel okullar ve dershanelere önemli bir kaynak aktarılması söz konusu olmuştur. 2020 yılında devlet, yaygın eğitim ve öğretim hizmetlerini yerine getirebilmesi için eğitime 177,6 milyar TL ayırmıştır. Bu tutar aynı yılın merkezi yönetim bütçesinin \%16,2 oranına karşılık gelmektedir (MEB, 2020). Örgün eğitimde özel okulların sayısının tüm okul sayısına oranı \%19,2 ve 20182019 yılında özel öğretime teşvikin kademeli olarak kaldırılması kararı alınmasına rağmen 2020 yılında hali hazırda öğrenimine devam eden 84.964 öğrenciye 329 
milyon TL ödenek ayrılmıştır (MEB, 2020). Özel öğrenime ayrılan bu ödenekler ve özel okulların sayılarındaki artış miktarı devletin eğitimin alanında yol açtı̆̆ı piyasalaşma yönündeki eğilime işaret etmektedir.

Devletin hem toplum üzerinde kontrol sağlama hem de kaynakların yeniden dağılımını etkilemek için sürekli ve çelişkili bir biçimde müdahale ettiği bir diğer alan olarak profesyonel meslek örgütleri (PMÖ) alanı sayılabilir (Özkara \& Özcan, 2004). Anayasada meslek örgütleri kamu tüzel kişiliğine haiz oldukları için kendilerine ait bütçeye, personele ve mal varlıklarına sahip olma hakları bulunmaktadır. Meslek örgütlerinin kamu tüzel kişiliğine sahip bulunmasının meslek mensuplarının devlet tarafindan kontrol edilmek istenmesinin bir neticesi olduğu belirtilmektedir (Aslan, 2013). Esasında sivil toplumun bünyesinde bulunması ve özel hukuk esaslarına göre faaliyette bulunması gereken meslek örgütlerinin, devletin bir organı haline getirilmesi, bazı meslek örgütlerinin belirli ideolojik konumları ve çıkarları savunması, zorunlu üyeliklerin bulunması, farklı örgütlenmelerin önündeki kanuni kısıtlamaların varlığı gibi nedenler, meslek örgütlerini özünden uzaklaştırmaktadır (Candan, 2011). Bu açıdan bakıldığında, meslek örgütlerinin devletle olan ilişkisi, devletin bu örgütlere müdahale biçimleri, söz konusu örgütleri belirleyen yasal sınırların ötesinde, kendine özgü, bağlamsal karakteristikler göstermektedir. Bu alan, devletin müdahalelerindeki çeşitliliği incelemek açısından araştırmaya değer niteliktedir.

Toplum üzerinde kontrol açısından düşük düzeyde etki potansiyeline sahip olan, ancak kamu kaynaklarının dağılımı konusunda yüksek düzeyde etki yaratabilen alanlarda gözlemlenen devlet davranışı "alana dahil aktör olma-sürekli müdahale" tipolojisi olarak ifade edilmiştir. Devletin kurumsal aktör olarak dahil olduğu, yani ana aktörlerden biri olarak rol aldığı, sürekli müdahalede bulunduğu ve kaynakların yeniden dağılımına yüksek oranda imkân sağlayan kurumsal alanlara tipik olarak inşaat, alt yapı ve sağlık alanları örnek verilebilir. Türkiye'de devletin ekonomide inşaat sektörüne dayalı bir büyüme modeli benimsemesi ve kalkınma hedefini bu alan üzerinden sağlama politikası sonucunda, alanda faaliyette bulunan belli başlı şirketlerin ulaştı̆̆ iş hacmi (Şahin, 2015) devletin kaynakların yeniden dağılımındaki rolünü belirgin biçimde ortaya koymaktadır.

Neo-liberal ekonomik politikaların uygulanmaya başlandığı 1980 ve sonrasında devlet birçok alandan çekilirken, inşaat kurumsal alanında Toplu Konut İdaresi (TOKI) kamusal bir aktör olarak devlet adına doğrudan üretime ve kaynakların aktarımına devam etmiştir (Eşkinat, 2012; Yeşilbağ, 2020). 2003 yılında dönemin iktidar partisi tarafından konut seferberliği başlatılmış, bu kapsamda TOKİ, kira 
öder gibi taksitlerle gelir düzeyi düşük yoksul halk kesimlerini ev sahibi yapmak ve istihdam sağlamak gibi amaçlarla faaliyetlerini sürdürmüştür (Eşkinat, 2012). İnşaat alanında en çok harcamanın yapıldığı ülkelerin başında gelen Türkiye'de (Alper, 2017) devlet, çıkarılan düzenleyici yasalar, sıkça değişen yönetmelikler ile alana sıkça müdahale etmiştir.

Öte yandan altyapı projelerine yönelen kamu harcamaları da önemli bir kaynak transferi işlevi görmektedir. Neo-liberal politikaların ön planda olduğu Uluslararası Para Fonu (IMF) ve Dünya Bankası gibi kurumların yönlendirdiği serbest ekonomi politikalarının gelişmekte olan ülkelerde uygulanmaya başlaması ile bu ülkelerde devletin ekonomideki kalkınmacı pozisyonu azaltılmıştır (Soyak, 2003). Türkiye’de de altyapı hizmetlerinin gerçekleşmesinde özel sektörün uzun süreli kamu hizmetlerine katılımı ile oluşturulan Kamu - Özel İşbirlikleri (KÖİ) yoluyla, altyapı yatırımları için duyulan finansmanın özel sektör aracılığıyla sağlanmasına yönelik bir yapılanmaya gidilmiştir (Emek, 2009). Altyapı hizmetlerinde KÖİ yönteminin kullanılmasının en önemli nedenleri, devletin var olan risklerin büyük bir kısmını özel sektöre devretmesi, hizmet sunumunda verimliliğin artırılması ve makro yatırımlara ek kaynak oluşturulabilmesidir (Emek, 2014). Sonuç olarak devletin, hazine garantili projeler/ihaleler vermesi, riskleri kendisinin üstlenmesi ve kaynakları kendi eliyle ve kendisinin belirlediği belirli özel sektör gruplarına aktarması, altyapı alanında kaynakların yeniden dağıtımının belirgin biçimde gözlemlenmesini sağlamaktadır.

Türk sağlık alanında da yapılan farklı çalışmalarda devletin önceliklerinin 1980'li yıllara kadar geleneksel kamu hizmeti olduğu, 1980 sonrasında yavaş yavaş piyasa mantığının egemenliğinin belirginleşmeye başladığı ve 2003 (Sağlıkta Dönüşüm Programı) sonrası bunun kamu hastanelerinin yönetimine de yansıdığı gözlemlenmiştir (Koç, 2012; Akdağ, 2011; Özseven vd., 2014; Özseven vd., 2016). Bir yandan devlet olmanın bir vasfı olarak kabul edilen sağlık hizmetlerinin kamu hizmeti olarak sunulması devam ederken, diğer bir deyişle devlet alanda güçlü bir aktör olarak bulunurken, diğer yandan giderek güçlenen piyasa mantığı, kaliteli ve düşük maliyeti önceleyen sağlık hizmeti arzı gerçekleştirmeyi sürdürerek sağlık alanında varlığını sürdürmektedir (Özseven vd., 2014). Piyasa mantığını önceleyen ve özel sağlık hizmetlerine, girişimlere, sigorta sistemlerine alan açan düzenlemeler sağlık alanında hem devleti ana aktör olarak tutmuş hem de önemli bir kaynak aktarımı imkanının da yollarını açmıştır.

Belirtilen alanlardaki farklı devlet eylemliliğine bakıldığında, devletin bir kurumsal aktör olarak oynadığı rollerdeki değişkenlik açık biçimde kendini 
göstermektedir. Milli eğitim alanında daha çok siyasi söylem birliği, makbul vatandaş kimliği yaratma hedefi üzerinden ideolojik kontrole yönelen devlet (Taş \& Hızıroğlu, 2016), Cumhuriyet tarihi boyunca sürekli olarak bu alana müdahale edegelmektedir. Başka bir kurumsal alan olan sağlık alanında ise devlet hem kendisi bir ana hizmet üreticisi olarak rol almakta hem de piyasalaştırma ve kamu ihaleleri yoluyla gelir aktarımına imkân sağlamaktadır. Bu alanda yapılan çalışmalar, sağlık alanında piyasalaşma eğiliminin, diğer bir deyişle özel sektörün oranının ve ağırlığının arttığını, öte yandan devletin de rekabetçi bir yaklaşımla kamu hastanelerini işletme benzeri bir mantıkla yönetmeye yöneldiğini göstermektedir (Özseven vd., 2016; Özseven vd., 2014). Öte yandan, yine aynı devlet, sinema/tiyatro alanında sessiz veya zaman zaman sadece kısıtlayıcı bir aktör olarak ortaya çıkarken (Kalemci \& Özen, 2011; Konur, 2001), STK'ların bir bölümünü görmezden gelebilmekte, faaliyetlerini denetim dışı bırakarak onları toplumu kontrol etmek amacıyla işlevselleştirebilmektedir (Bulut vd., 2017). Bu tartışmalardan yola çıarak, Türkiye'de devletin kurumsal alanlara müdahalesinin gerekçesi olarak bazı önceliklerinin bulunduğunu, her alana benzer şekilde müdahale etmediğini, farklı alanlarda değişen eylem biçimleri benimsediğini söylemek mümkün görünmektedir.

\section{Değerlendirme ve Sonuç}

Yeni kurumsalcı kuram, doğduğu ve geliştiği bağlamın izlerini taşıyan bir devlet tahayyülü üzerinden örgütler, örgütsel alanlar ile devletin ilişkisini ortaya koymaktadır. Bu perspektiften devlet, ağırlıklı olarak Weberyan manada siyasi ve ekonomik alanları ayrıştırabilme kapasitesine sahip ve liberal sistematik içinde rasyonel, tarafsız, düzenleyici bir aktör olarak varsayılmaktadır. Bu varsayım, devletin bir kurumsal girişimci olarak konumunu ve giriştiği kurumsal işleri de belirleyen bir düşünsel izlek yaratmaktadır. Ancak kamu yönetimi, siyaset bilimi ve iktisat alanında özellikle 1980 ve sonrasında süregiden tartışmalar, bizzat devlet kavramının kendisine ilişkin kuramsal ve düşünsel değişimi, devlet aygıtlarında ve fonksiyonlarındaki dönüşümü ortaya koymaktadır. Devletin tanımının, toplum içerisindeki konumunun, eylemlerinin, kapitalizmin krizleri, sermayenin küreselleşmesi ve neoliberal politikalardan ayrı düşünülemeyeceğinin altı çokça çizilmektedir.

$\mathrm{Bu}$ tartışmalar, örgüt kuramları ve yeni kurumsalcı kuram açısından Amerika ve Avrupa bağlamına da çok fazla yansımış görünmemektedir. Yeni kurumsalcı kuramda devletin bir kurumsal aktör olarak yeterince analize dahil edilmediği açıktır. Anglo Amerikan dünya dışındaki ülkelerde de devletin kurumsal işleri yoğun bir 
araştırmaya tabi tutulmuş değildir. Örgüt araştırmalarında devlet, devletin örgütler ve kurumsal alanlar ile ilişkisi, yarattı̆̆ı sonuçlar, ilgili yazında adeta bir "kayıp parça" gibi durmaktadır.

Öte yandan yeni kurumsalcı kuramda devlet, bir kurumsal girişimci olarak "oyunun kurallarını belirleyebilen, kurumsallörgütsel alanların disıında, çıkarları çatı̧̧an aktörlerin arasinda arabulucu pozisyonda, istikrarın ve değişimin ana kaynă̆g" biçiminde nitelendirilirken Türkiye bağlamındaki araştırmalar ve tartısmalar, "bir kurumsal aktör olarak örgütsel alanları içinde, kural koyma ve uygulama kapasitesi sinırl, istikrar yerine belirsizlik yaratan, eksik kurumsallaşma ve çeşitlenmeye yol açan" bir devlet eylemliliği resmetmektedir. Bu değişkenlik, farklı siyasal-toplumsal sistemlerde hâkim devletlerin oynadığı kurumsal girişimci rollerinin açılanmaya muhtaç olduğu gerçeğini ortaya koymaktadır.

$\mathrm{Bu}$ çalışma, $\mathrm{ABD}$ orijinli yeni kurumsal kuramın devlete ilişkin temel varsayımlarından yola çıkarak, farklı siyasal toplumsal sistemlerin egemen olduğu ülkelerde devletin bir kurumsal girişimci olarak rolünün ve kurumsal işlerinin nasıl bir değişkenlik gösterebileceği sorusuna cevap aranmıştır. Türkiye, kendine özgü bir siyasal sisteme sahip, fakat aynı zamanda uzun süredir neoliberal politikalar üzerinden dünya kapitalizmi ile eklemlenme sürecinde olan, devletin örgütsel alanlar ile ilişkisinin ve bir kurumsal girişimci olarak sergilediği eylemlerin yeni kurumsalcı kuramın mevcut devlet varsayımları ile tam olarak açıklanamayacağı, farklı siyasal-toplumsal sistemler içerisinde ortaya çıkan devlet eylemliliğinin, örgütler ve örgütsel/kurumsal alanlarla ilişkiler açısından değişkenlik arz ettiği bir ülke olarak söz konusu soruya cevap vermek için uygun bir bağlamı temsil ediyor görünmektedir.

Türkiye'deki devlet eylemlerine ilişkin tartışmalar ile yine Türkiye bağlamını esas alan ve devletin kurumsal girişimci rollerine odaklanan araştırmalar göz önüne alındığında, devletin farklı kurumsal alanlarla farklı biçimlerde ilişkilendiği ve kurumsal işlerinin de bunlara göre değişkenlik arz ettiği görülmektedir. Bu davranış çeşitliliği de çeşitli kurumsal iş kategorileri tanımlamaya imkân sağlamaktadır. Bu doğrultuda çalışmada, devletin eylemleri "toplum üzerinde kontrol sağlama" ve "kaynakların yeniden dağılımına imkân yaratma" saiklerine göre, "görmezden gelme", "çelişkili-sürekli müdahale", "dönemsel-pragmatik müdahale", "alana dahil aktör-sürekli müdahale" biçiminde dört farklı şekilde kavramsallaştırılmıştır. Bu kavramsallaştırma içinde devlet, örneğin bazı sivil toplum kuruluşlarının faaliyetlerini, toplum üzerinde kontrol sağlama ve yönlendirme saikiyle görmezden gelebilmektedir. Öte yandan, devlet, toplumu kontrol etme ve kaynakların yeniden dağılımına imkân 
verme açısından düşük kapasiteye sahip kültür, sanat, spor gibi alanlardaki örgütlerin davranışlarına, dönemsel, pragmatik ve kısmi biçimlerde müdahale edebilmektedir. Aynı devlet, milli eğitim gibi bir alandan ilgisini hiç çekmemekte, bu alanı farklı hükümet dönemlerinde içeriği/söylemi değişen ancak temel saiki değişmeyen (ulus kimliği yaratmak-dindar nesil yaratmak gibi) biçimde sürekli olarak düzenlemektedir. Söz konusu alan, aynı zamanda piyasalaşma ve kaynak transferine de imkân vermekte ve birçok çelişkili müdahale nedeniyle yüz yıla yaklaşan Cumhuriyet rejimine rağmen tam olarak kurumsallaşamamıştır. Son olarak politik/ideolojik olarak toplumu kontrol etme potansiyeli taşımayan ancak büyük ölçüde piyasalaşma ve kaynak aktarımı potansiyeli olan inşaat, sağlık, altyapı gibi sektörlerde devlet kendisini üretici konuma almakta, alanda bir aktör olarak davranmakta, büyük sermaye hareketlerine yön vermekte ve sürekli düzenlemelere girişebilmektedir.

Ortaya konan bu çerçeve, dolayısıyla tanımlanan değişken kurumsal iş kategorileri, öncelikle yeni kurumsalcı kuramın devlet kavramsallaştırmasına ilişkin varsayımlarına farklı bir bağlamdan katkı sunmayı amaçlamaktadır. Yukarıda sayılan nedenlerle, yeni kurumsal kuramın "alanların dışında, rasyonel, kural koyucu, tarafsız bir devlet tasavvuru", tadil edilmeye ihtiyaç duyan bir aşamaya gelmiş görünmektedir. Öte yandan bu çalışma, Türkiye bağlamının biricikliğini ve aynı zamanda küresel sistemle ilişkilerini ve etkileşimini anlamaya dönük tartışmaları zenginleştirmek açısından da önem taşımaktadır. Örgüt araştırmalarında devletin rolünün, kurumsal/örgütsel alanlara karşı konumu ve yarattığı etkilerin anlaşılması kadar, bu etkilerin yeni çalışmalarla Türkiye açısından gözlemlenmesi ve açıklanabilmesi hem kuramsal hem de pratik açıdan değerli katkılar sağlama potansiyeline sahiptir.

$\mathrm{Bu}$ araştırmanın yöneldiği kuramsal tartışma ve ortaya koyduğu model, devletin kurumsal işlerinin analitik bir çerçeveden incelenmesi, araştırılması ve sonraki örgüt araştırmalarına temel oluşturması açısından önem taşımaktadır. Bu açıdan çalışmada tartışılan ve önerilen kurumsal iş kategorileri, bir dizi yeni araştırma sorusunu da beraberinde getirmektedir. Öncelikle bu çalışmada ortaya konan kurumsal iş kategorilerinin geçerliliğine ilişkin çok sayıda ve geniş araştırmalara ihtiyaç olduğu açıktır. Farklı kurumsal alanlarda, devletin konumunun nasıl olduğu, ne tür kurumsal işlere giriştiği, bu kurumsal işlerin arkasında nasıl bir devlet motivasyonu olduğu soruları cevaplanmaya muhtaçıır. Türkiye'de hali hazırda yapılmış çalışmalar, ağırlıklı olarak eğitim ve sağlık alanlarına yoğunlaşmış görünmektedir. Oysa bu iki alan hem niteliği hem de ülkedeki tarihselliği açısından kamusal karakter taşımaktadır. Özel sektörün çok daha ağırlıklı olduğu, deyim yerinde ise piyasa mantığının öteden beri daha ağır bastığı basın yayın, turizm, tütün ürünleri ve alkollü içecekler, ilaç/ 
kimya gibi alanlarda devletin konumu ve giriştiği kurumsal işlerin ne olduğuna dair bir akademik sessizliğin olduğu söylenebilir. Genel olarak Türkiye'deki örgüt araştırmalarında da devlet ve onun davranışları, az çalışılan, çok ilgi gösterilmeyen, bir biçimde sessiz kalınan bir olgu niteliğindedir. Bu durum bile, devletin giriştiği kurumsal işlerin çeşitliliğine bir araştırma zemini oluşturmaktadır.

Öte yandan devletin kurumsal/örgütsel alanlar ile ilişkisini, bir kurumsal girişimci olarak pozisyonunu ve giriştiği kurumsal işleri açıklamaya çalışmak, deyim yerindeyse madalyonun bir yüzünü oluşturmaktadır. Devletin kurumsal alanlara müdahale gerekçesi ve biçimlerindeki değişim kadar, söz konusu alanlarda yarattığı etkiler ya da sonuçlar da özellikle işletme örgütleri açısından önem taşımaktadır. Türkiye bağlamında devletin taraflı ve oyuncu bir kimlikle alanlara dahil olduğu, düzenleyici araçların (yasa, yönetmelik, mevzuat vb.) sıklıkla değiştiği, çeşitli örgütsel formların ortaya çıktığı ancak sürekli/istikrarlı hale gelemediği, merkezi kararlar ile örgütsel uygulama ya da formların ortadan kalkabildiği, eksik kurumsallaşmanın kendisinin kurumsallaştığı pek çok sektör ve mesleki alanlar bulunmaktadır. Dolayısıyla söz konusu alanlardaki devlet girişimciliğinin, örgütler, örgütsel performans, örgütsel formlar, kurumsal alanlar, kurumsallaşma, eksik kurumsallaşma, sektörel etkinlik vb. birçok konuda yarattığı sonuçlar incelenmeye değer konular arasındadır. Bu sonuçların gözlemlenmesi hem kuramsal açıdan önemli katkılar sağlama hem de Türkiye'deki örgütsel gerçekliği anlamaya ve açıklamaya katkıda bulunma potansiyeli taşımaktadır. Örneğin basın yayın alanında son yirmi yılda yaşanan değişim ve bunlarla ilgili devletin eylemleri ve politikaları, devletin kurumsal girişimci rolü, bunun sonuçları ve söz konusu alanın işlevselliği, etkinliği, hatta etiği açısından bize neler söyleyebilir? Aynı biçimde tütün ve alkollü içecek piyasasına ilişkin düzenlemeler, bu alandaki örgütler, yerli ve yabancı yatırımcılar, oyunun kuralları, sektörün büyüklüğü, uluslararası rekabeti ve hatta tüketim alışkanlıkları açısından hangi sonuçları doğurmaktadır? Buradan, işletme örgütleri, onların etkinliği, sahiplik yapıları, örgütsel formları, alanların kurumsallaşma ya da kurumsal değişim süreçlerine ilişkin ne tür çıkarımlar yapılabilir?

Son tahlilde Türkiye bağlamı, bir kurumsal girişimci olarak devlet, devletin kurumsal işleri, bunların işletmeler/örgütler ve örgütsel alanlar üzerinde yarattı̆̆ı etkiler hem kuramsal katkıya hem de örgütlerin günlük pratiklerini ve davranışlarını anlamaya imkân sağlayan çok bakir bir araştırma alanı olarak akademik camianın ilgisini beklemektedir. Örgüt araştırmalarında farklı analiz düzeyleri arasındaki etkileşimleri ve bağlamlar arası farklılıkları bir araya getirebilen daha zengin bir kuramsal kavrayış için, devletin bu alandaki izlerini gözlemlemeye ve tanımlamaya daha fazla ihtiyaç olduğu açıktır. 


\section{Kaynakça / References}

Akçay, Ü. 2013. Sermayenin uluslararasılaşması ve devletin dönüşümü: Teknokratik otoriterizmin yükselişi. Praksis, O(30-31): 11-39.

Akdağ, R. 2011. Türkiye sağlıkta dönüşüm programı değerlendirme raporu (20032011).

Alper, A. E. 2017. İnşaat sektörünün ekonomik büyümedeki rolü: Türkiye örneği. Çukurova Üniversitesi Sosyal Bilimler Enstitüsü Dergisi, 26(2): 239-252.

Aslan, Z. 2013. Meslek kuruluşlarına zorunlu üyeliğin üzerine hukuki bir değerlendirme. Dokuz Eylül Üniversitesi Hukuk Fakültesi Dergisi, 1240(Special): 1229-1240.

Ayık, H. 2016. Din - devlet ilişkileri bağlamında islâmî cemaatlerin devletle ilişkileri üzerine. Artvin Çorub Üniversitesi Uluslararası Sosyal Bilimler Dergisi, 2(1): 62-77. https://doi.org/10.22466/acusbd.263585

Battilana, J. 2006. Agency and institutions: The enabling role of individuals' social position. Organization, 13(5): 653-676. https://doi.org/10.1177/1350508406067008

Battilana, J., Leca, B., \& Boxenbaum, E. 2009. How actors change institutions: Towards a theory of institutional entrepreneurship. Academy of Management Annals, 3(1): 65-107. https://doi.org/10.5465/19416520903053598

Birkiye, S. K. 2012. Kültür politikaları, Türk tiyatrosu ve DT örneği. Tiyatro Eleştirmenliği ve Dramaturji Bölüm Dergisi, 78-107.

Brown, W. 2006. American nightmare: Neoliberalism, neoconservatism, and de-democratization. Political Theory, 34(6): 690-714.

Brown, W. 2010. Taribten çıkan siyaset (Çev. Emine Ayhan) (1.Edition). Metis Yayınları.

Buğra, A. 1994. State and business in Turkey. Albany: State University of New York Press.

Buğra, A. \& Savaşkan, O. 2015. Türkiye’de yeni kapitalizm (3. baskı). İletişim Yayınları.

Bulut, Y., Akın, S., \& Kahraman, Ö. F. 2017. Kamu politikalarının oluşturulmasında sivil toplum kuruluşlarının etkisi. Strategic Public Management Journal, 3(6): 23-34. https://doi.org/10.25069/spmj.341620

Candan, E. 2011. Türkiye’ de kamu kurumu niteliğindeki meslek kuruluşlarının yeniden yapılandırlmasina ilişkin reform önerisi. http://www.liberal.org.tr/upresimler/Reform_Onerisi.pdf (Erişim: 20/01/2021)

Dağ, R. \& Kılıç, A. R. 2019. Din-devlet ilişkileri açısından menzil cemaati örneği. Journal of Turkish Studies, 14(1): 205-226. https://doi.org/10.7827/turkishstudies. 14887

Dimaggio, P. 1983. State expansion and organizational fields. R. H. Hall \& R. E. Quinn (Ed.), Organization Theory and Public Policy:147-161. Beverly Hills: Sage. 
DiMaggio, P. J. 1988. Interest and agency in institutional theory. L. G. Zucker (Ed.), Institutional patterns and organizations: 3-32. Ballinger Publishing Company.

DiMaggio, P. J. \& Powell, W. W. 1991. The new institutionalism in organizational analysis. Chicago: University of Chicago Press.

DiMaggio, P. \& Powell, W. W. 1983. The iron cage revisited : Institutional isomorphism and collective rationality in organizational fields. American Sociological Review, 48(2): 147-160. https://doi.org/10.1016/j.jclepro.2015.02.067

Dirlik, O. 2016. Türk iş sisteminin evrimi: Makro kurumsal bir inceleme. Yönetim ve Organizasyon Araştırmalar Dergisi, 1(2): 5-29.

Efe, A. 2017. Kolektif dindarlık türü olarak tarikat/cemaat dindarlığı. Journal of Islamic Research, 28(3): 290-301.

Eisenstadt, S. N. 1980. Cultural orientations, institutional entrepreneurs, and social change: Comparative analysis of traditional civilizations. American Journal of Sociology, 85(4): 840-869. https://doi.org/10.1086/227091

Emek, U. 2009. Türkiye’de altyapı hizmetlerinin özel sektöre gördürülmesi: Neden, ne zaman, nasıl? Iktisat Issletme ve Finans, 24(284): 9-45. https://doi.org/10.3848/ iif.2009.284.2456

Emek, U. 2014. Kamu-özel işbirliklerinin devlet muhasebe sistemindeki yeri ve önemi. İktisat Işletme ve Finans, 29(337): 9-38. https://doi.org/10.3848/iif.2014.337.4024

Emrence, C. 2010. From elite circles to power networks: Turkish soccer clubs in a global age, 1903-2005. Soccer and Society, 11(3): 242-252.

Erkoç, G. 1995. Çok partili dönemde tiyatro ortamı ve kimlik arayışı. Tiyatro Araştırmalarn Dergisi, 12(12): 17-25.

Eşkinat, R. 2012. Türk inşaat sektöründe (TOKI’NİN) yeri ve etkisi. Dumlupınar Üniversitesi Sosyal Bilimler Dergisi, 32(2): 159-172.

Fligstein, N. 1990. The transformation of corporate control. Harvard University Press.

Fligstein, N. 1991. The structural transformation of american industry: An institutional account of the causes of diversification in the largest firms, 1919-1979. W. W. Powell \& P. J. DiMaggio (Ed.), The new institutionalism in organizational analysis:311-336. Chicago: University of Chicago Press.

Fligstein, N. 2001. Social skill and the theory of fields. Sociological Theory, 19(2): 105125. https://doi.org/10.1111/0735-2751.00132

Garud, R., Hardy, C., \& Maguire, S. 2007. Institutional entrepreneurship as embedded agency: An introduction to the special issue. Organization Studies, 28(7): 957969. https://doi.org/10.1177/0170840607078958 
Gökoğlu, M. M. 2012. Çalışanların gelecek güvencesi: Türkiye’de sosyal sigorta mantığının oluşumu, 1921-1950. Yayınlanmamış Doktora Tezi. Başkent Üniversitesi, Sosyal Bilimler Enstitüsü, Ankara.

Gourisse, B. 2016. Nizam vermek/emretmek ve uzlaşmak: Türkiye ve Osmanlı İmparatorluğu'nda somut olarak kamusal icraat. M. Aymes, B. Gourisse, \& E. Massicard (Ed.), Devlet olma zanaatı: Osmanlidan bugüne kamu icraatı: 7-30. İstanbul: İletişim Yayınları.

Greenwood, R., Suddaby, R., \& Hinings, C. R. 2002. Theorizing change : The role of professional associations in the transformation of institutionalized fields. Academy of Management, 45(1): 58-80. https://doi.org/10.5465/AMJ.2009.43670890

Heper, M. 1991. The state and interest groups with special reference to Turkey. M. Heper (Ed.), Strong state and economic interest groups: The post-1980 Turkish experience :3-23. Berlin, New York: de Gruyter.

Holm, P. 1995. The dynamics of institutionalization : Transformation processes in norwegian fisheries. Administrative Science Quarterly, 40(3): 398-422.

Jepperson, R. L. 2002. Political modernities: Disentangling two underlying dimensions of institutional differentiation. Sociological Theory, 20(1): 61-85.

Jepperson, R. L. \& Meyer, J. W. 1991. The public order and the construction of formal organizations. içinde W. W. Powell \& P. J. DiMaggio (Ed.), The new institutionalism in organizational analysis: 204-231. University of Chicago Press,.

Kalemci, R. A. \& Özen, S. 2011. Türk sinemacılık sektöründe kurumsal değişim (19502006): Küreselleşmenin 'sosyal dışlama' etkisi. Amme Ídaresi Dergisi, 44(1): 51-88.

Koç, O. 2012. Kurumsal mantıklar arasındaki rekabetin yönetimi: Türk sağlık alanı kapsamında karşılaştırmalı bir analiz. 3. Örgüt kuramı çalıştayı bildiriler kitabı: 71-103.

Koç, U. 2013. Taking the state seriously : The effects of the state on institutional change and the field-level logics. 4. Örgüt kuramı çalıştayı bildiriler kitabı: 23-51.

Koç, U., Özen-Aytemur, J., \& Erdemir, E. 2016. Powerful actor and hesitant institutionalization: The state in the history of Turkish football. International Journal of the History of Sport, 33(16): 1904-1920.

Koç, U., Özen-Aytemur, J., \& Erdemir, E. 2011. Türkiye’ de kurumsal bir aktör olarak devlet ve futbol. 2. Örgüt kuramı çalıştayı bildiriler kitabı: 137-152.

Konur, T. 2001. Cumburiyet döneminde devlet-tiyatro ilişkisi. Dost Yayınları.

Kraatz, M. S. \& Moore, J. H. 2002. Executive migration and institutional change. Academy of Management, 45(1): 120-143. 
Lawrence, T. B. \& Phillips, N. 2004. From moby dick to free willy: Macro-cultural discourse and institutional entrepreneurship in emerging institutional fields. Organization, 11(5): 689-711. https://doi.org/10.1177/1350508404046457

Lawrence, T. B., \& Suddaby, R. 2006. Institutions and institutional work. S. R. Clegg, C.Hardy, T. B. Lawrence, \& W. R. Nord (Ed.), The Sage handbook of organization studies: 215-254. Sage Publications, Thousand Oaks.

Lawrence, T., Suddaby, R., \& Leca, B. 2011. Institutional work: Refocusing institutional studies of organization. Journal of Management Inquiry, 20(1): 52-58.

Leblebici, H., Salancik, G. R., Copay, A., \& King, T. 1991. Institutional change and the transformation of interorganizational fields : An organizational history of the U . S . radio broadcasting industry. Administrative Science Quarterly, 36(3): 333-363.

Maguire, S., Hardy, C., \& Lawrence, T. B. 2004. Institutional entrepreneurship in emerging fields: Hiv/Aids treatment advocacy in canada. Academy of Management Journal, 47(5): 657-679. https://doi.org/10.2307/20159610

Mardin, Ş. 1992. Ídeoloji (1.ed). İletişim Yayınları.

MEB.2020. 2020 yılı bïtçe sunum raporu .

https://sgb.meb.gov.tr/meb_iys_dosyalar/2019_12/18094404_2020_BUTCE_SUNU_ YU_17.12.2019.pdf

Meyer, J. W., \& Rowan, B. 1977. Institutionalized organizations: Formal structure as myth and ceremony. Acamerican Journal of Sociology, 83(2): 340-363.

Mollaer, F. 2016. Tekno mubafazakârlı̆̆ın eleştirisi: Politik denemeler (1.Baskı). İletişim Yayınları.

Nasra, R., \& Dacin, M. T. 2010. Institutional arrangements and international entrepreneurship: The state as institutional entrepreneur. Entrepreneurship: Theory and Practice, 34(3): 583-609. https://doi.org/10.1111/j.1540-6520.2009.00354.x

Oğuz, Ş. 2012. Türkiye'de kapitalizmin küreselleşmesi ve neoliberal otoriter devletin inşası. Türk Tabipler Birliği, Mesleki Sağlık ve Güvenlik Dergisi, 12(45): 2-15.

Öz, B. H. \& Belkıs, Ö. 2017. Türkiye'de alternatif tiyatro yapılanmalarında kadın liderliği ve bir örnek: Yeşim özsoy - galataperform. International Journal of Interdisciplinary and Intercultural Art, 2(2): 1-22. https://doi.org/10.29228/ijiia.2.12

Özen, Ş. 2011. Yeni kurumsal kuramın dayandığı siyasal sistem varsayımları ve Türkiye açısından bir değerlendirme. F. Kartal (Ed.), Türkiye’de kamu yönetimi ve kamu politikaları: 45-66. Ankara: Türkiye ve Orta Doğu Amme İdaresi Enstitüsü Yayınları.

Özen, Ş. 2014. Recontextualizing the new institutional conception of the state to the Turkish case. R. Westwood, G. Jack, F. Khan \& M. Frenkel (Ed.), Core-periphery relations in organization studies: 79-99. Basingstoke: Palgrave McMillan. 
Özen, Ş. 2010. yeni kurumsal kuramın dayandığı siyasal sistem varsayımları ve türkiye açısından bir değerlendirme. 1. Örgüt kuramı çalıştayı bildirileri kitabı, 17-32.

Özen, Ş. \& Akkemik, K. A. 2012. Does illegitimate corporate behaviour follow the forms of polity? The Turkish experience. Journal of Management Studies, 49(3): 515537. https://doi.org/10.1111/j.1467-6486.2011.01007.x

Özen, Ş. \& Özen, H. 2009. Peasants against MNCs and the state : The role of the bergama struggle in the institutional construction of the gold-mining field in Turkey. Organization, 16(4): 547-573. https://doi.org/10.1177/1350508409104508

Özkara, B. \& Özcan, K. 2004. Bir kurumsal alanın doğuşu ve evrimi:Türkiye’de muhasebenin meslekleşme süreci. Yönetim Araştırmaları Dergisi, 4(2): 197-230.

Özseven, M., Danışman, A., \& Bingöl, A. S. 2014. Dönüşüm mü, gelişim mi? Kamu hastanelerinin yönetiminde yeni bir kurumsal mantığa doğru. ODTÜ Gelişme Dergisi, 41, 119-150.

Özseven, M., Danışman, A., \& Bingöl, A. S. 2016. Kurumsal değişim, güç mekanizmalar1 ve direniş taktikleri: Türk sağlık alanında bir araştırma. ODTÜ Gelişme Dergisi, 43(12): 779-811.

Palmer, D. \& Biggart, N. W. 2002. Organizational institutions. J. A. C. Baum (Ed.), Blackwell companion to organizations: 259-280. Oxford: Blackwell.

Rowan, B. 1982. Organizational structure and the institutional environment: The case of public schools. Administrative Science Quarterly, 27(2): 259-279.

Şahin, Ç. 2015. Türkiye'de kentsel dönüşüme dayalı inşaat odaklı ekonomi modeli ve toplumsal maliyeti: En temel insan hakları, sosyal haklar, çevre hakkı ve kent hak$\mathrm{k} 1$ açısından eleştirel bir değerlendirme. Istanbul Journal of Sociological Studies, O(51): 51-81. https://doi.org/10.18368/iu/sk.09445

Şahin, M. \& Uysal, Ö. 2007. Sivil toplum kuruluşlarının devlet tarafından finansmanı üzerine bir tartışma. Maliye Dergisi, 153, 1-13.

Savut, E. 2014. Türkiye’de sanat-siyaset ilişkisi bağlamında devlet tiyatroları örneği. Dokuz Eylül Üniversitesi, Sosyal Bilimler Enstitüsü, Yayınlanmamış Yüksek Lisans Tezi.

Saymaz, İ. 2019. Şehvetiye tarikatı (1. Edition). İletişim Yayınları.

Scott, W. R. 2003. Organizations: rational, natural, and open systems (5.edition). Upper Saddle River.Prentice Hall.

Selznick, P. 1957. Leadership in administration; a sociological interpretation. Row, Peterson.

Seo, M. G. \& Creed, W. E. D. 2002. Institutional contradictions , and institutional change : A dialectical perspective. Academy of Management Review, 27(2): 222-247. 
Şimşek, U., Küçük, B., \& Topkaya, Y. 2012. Cumhuriyet dönemi eğitim politikalarının ideolojik temelleri. Turkish Studies-International Periodical For The Languages, Literature and History of Turkish or Turkic, 7(4): 2809-2823.

Skocpol, T. 1985. Bringing the state back in: Strategies of analysis in current research. içinde E. Peter B., R. Dietrich, \& T. Skocpol (Ed.), Bringing the state back in: 3-38. Cambridge University Press. https://doi.org/10.1017/cbo9780511628283.002

Soyak, A. 2003. Türkiye'de iktisadi planlama: DTP'ye ihtiyaç var mı? Doğuş Üniversitesi Dergisi, 4(2): 167-182.

Taş, A. \& Hızıroğlu, M. 2016. İdeolojinin kurumsal değişimdeki rolü : Eğitim kurumu üzerinden türkiye eksenli bir değerlendirme. İsletme Bilim Dergisi, 4(2): 71-104.

Tempel, A. \& Walgenbach, P. 2007. Global standardization of organizational forms and management practices? What new institutionalism and the business-systems approach can learn from each other. Journal of Management Studies, 44(1): 1-24.

Türkeli, S. 2012. Kurumsal alanın oluşumu ve değişiminde mikro-makro aktör ve yapıların etkileşimi: Türkiye'deki tam teşekküllü özel hastaneler alanı örneği. Yayınlanmamış Doktora Tezi. İstanbul Teknik Üniversitesi, Fen Bilimleri Enstitüsü, İstanbul.

Uygun, S. 2003. Türkiye'de dünden bugüne özel okullara bir bakış (gelişim ve etkileri). Ankara Üniversitesi Egitim Bilimleri Fakültesi Dergisi, 36(1-2): 107-120.

Whitley, R. 2005. How national are business systems? The role of states and complementary institutions in standardizing systems of economic coordination and control at the national level. G. Morgan, R. Whitley and E. Moen (Ed.), Changing capitalisms? Internationalization, institutional change, and systems of economic organization: 190-231. Oxford: Oxford University Press.

Yalçınkaya, A. 2018. Devletin kurumsal süreçlere etkisi: Türkiye kaynaklı yeni kurumsal kuram çalışmaları üzerine sistematik bir yazın değerlendirmesi (1998-2016). Siyasal Bilgiler Fakültesi Dergisi, (ISMUS), 3(1): 29-53.

Yalçınkaya, A. \& Taşcı, D. 2017. Bir kurumsal girişimci olarak devlet : Yeni kurumsal kuram bağlamında bir değerlendirme. Yönetim ve Organizasyon Araştırmaları Dergisi, 2(1): 71-89.

Yalçınkaya, A. \& Taşcı, D. 2020. Devletin kurumsal girişimciliği: Türk havayolu taşımacılığı alanında slot tahsisine ilişkin ardışık ve çelişik kurumsal işler (1992-2010). Anadolu Üniversitesi Sosyal Bilimler Dergisi, 20(2): 173-196.

Yeşilbağ, M. 2020. İnşaat sektörünün kriz dinamikleri : Güncel bir değerlendirme. Mülkiye Dergisi, 44(1): 101-130.

Yılmaz, M. 2018. Sivil toplum ve sivil toplum kuruluşları: Türkiye'de bilgi hizmetlerine yönelik oluşturulmuş STK'lar ve bu kuruluşlara yönelik bir araştırma. ZfWT / Journal of World of Turks, 10(1): 249-272. 
